\title{
Carbon pool and substitution effects of an increased use of wood in buildings in Switzerland: first estimates
}

\author{
Frank WERNER $^{\text {a* }}$, Ruedi TAVERNA ${ }^{\mathrm{b}}$, Peter HOFER $^{\mathrm{b}}$, Klaus RICHTER $^{\mathrm{c}}$ \\ a Environment and Development, Waffenplatzstrasse 89, 8002 Zurich, Switzerland \\ ${ }^{\mathrm{b}}$ GEO Partner AG, Baumacherstrasse 24, 8050 Zurich, Switzerland \\ c Swiss Federal Laboratories for Materials Testing and Research (Empa), Ueberlandstrasse 129, 8600 Duebendorf, Switzerland
}

(Received 13 April 2004; accepted 6 October 2005)

\begin{abstract}
Long-living wood products can contribute to the mitigation of climate change in many ways. On the one hand, they act as a carbon pool during their service life, as they withdraw $\mathrm{CO}_{2}$ from its natural cycle. After their service life, they can substitute for fossil fuels if they are incinerated in adequate furnaces. On the other hand, wood products can substitute for more energy intense products made of 'conventional' materials. This paper quantifies the substitution and carbon pool effects of an increased use of wood in the building sector in Switzerland for the years 2000-2130. For this purpose, life cycle data on greenhouse gas (GHG) emissions of 12 wood products and their substitutes is used as proxies for the most important groups of building products used in construction and in interior works; this data is linked to the forecasted wood flows for each group of building products in a cohort-model. For the political assessment, GHG effects occurring abroad are distinguished from GHG effects occurring in Switzerland. The results show that the C-pool effect of an increased use of wood products with long service life is of minor importance; the substitution effects associated with the thermal use of industrial and post-consumer waste wood as well as with the substitution of 'conventional' materials are much more relevant, especially on a long-term. For construction materials, the Swiss share of the GHG effect related to the material substitution is relatively high, as mainly nationally produced concrete, mineral wool, and bricks are substituted for. For products used in interior works, the Swiss share of the GHG effect related to the material substitution is rather small (or even negative for single products) because mainly imports are substituted, such as ceramic tiles or steel produced in the EU. The results are rough estimates. Nonetheless, these calculations show that an increased use of wood in the building sector is a valid and valuable option for the mitigation of greenhouse gas emissions and for reaching GHG emission targets on a mid- to long-term basis. Still, the carbon storage and substitution capacity of an increased use of wood is relatively small compared to the overall greenhouse gas emissions of Switzerland.
\end{abstract}

wood products / substitution / sink / climate change / Kyoto protocol / life cycle assessment / GHG / $\mathrm{CO}_{2}$

Résumé - Effets de puits de carbone et de substitution par l'utilisation augmentée de bois dans les bâtiments en Suisse. Les produits en bois avec une longue durée de vie en service peuvent contribuer de manière diverse à la diminution des émissions de gaz à effet de serre. D'une part, ils forment un puits de carbone issu du $\mathrm{CO}_{2}$ retiré de l'atmosphère par l'arbre au cours de sa croissance. Après leur utilisation, ils peuvent se substituer aux combustibles fossiles s'ils sont incinérés dans des chaudières adéquates. D'autre part, le matériau bois peuvent se substituer à des matériaux « conventionnels » plus coûteux en énergie. Cet article quantifie les effets de la substitution et de puits de carbone qui résultent d'une utilisation augmentée de bois dans les bâtiments en Suisse de 2000 à 2130. Dans ce but, les valeurs de rejets de gaz à effet de serre de 12 produits de bois et de ses substituts sont utilisées comme approximations pour les ensembles de produits de construction et d'aménagement les plus importants. Ces valeurs sont combinées avec une prévision des flux de chaque ensemble de produits dans un modèle de cohortes. Pour l'évaluation politique des résultats, les émissions des gaz à effet de serre en Suisse sont distinguées des émissions à l'étranger. Les résultats indiquent que l'effet de puits d'une plus grande utilisation de bois à durée de vie longue est d'une moindre importance; les effets de substitution associés à la valorisation énergétique des déchets de bois industriel et des produits en fin de vie ainsi que les effets de substitution de matériaux «conventionnels» sont beaucoup plus significatifs, particulièrement dans une perspective à long terme. Concernant les produits de construction, les effets de substitution de matériaux sont relativement importants en Suisse, parce que dans la majorité des cas, se son les éléments construits en Suisse en béton ou en briques qui sont remplacés. En ce que concerne l'aménagement, les effets de substitution de matériaux en Suisse sont relativement petits (ou même négatif dans certains cas), parce que dans la majorité des cas, ce son des produits importés qui sont remplacés, par exemple des carreaux de céramique ou des éléments en acier fabriqués dans la CE. Les résultats de ces calculs doivent être considérés comme estimations. Cependant, ces calculs montrent qu'une plus grande utilisation de bois dans les bâtiments est une option valable visant à diminuer les émissions de gaz à effet de serre à moyen et long terme. Mais la capacité de puits et de substitution d'une utilisation augmentée de bois est relativement petite, si on la compare avec le total des rejets de gaz à effet de serre en Suisse.

produits en bois / substitution / puits / changement climatique / protocole de Kyoto / analyse de cycle de vie / gaz à effet de serre / $\mathrm{CO}_{2}$

\footnotetext{
* Corresponding author: frank.werner@gmx.ch
} 


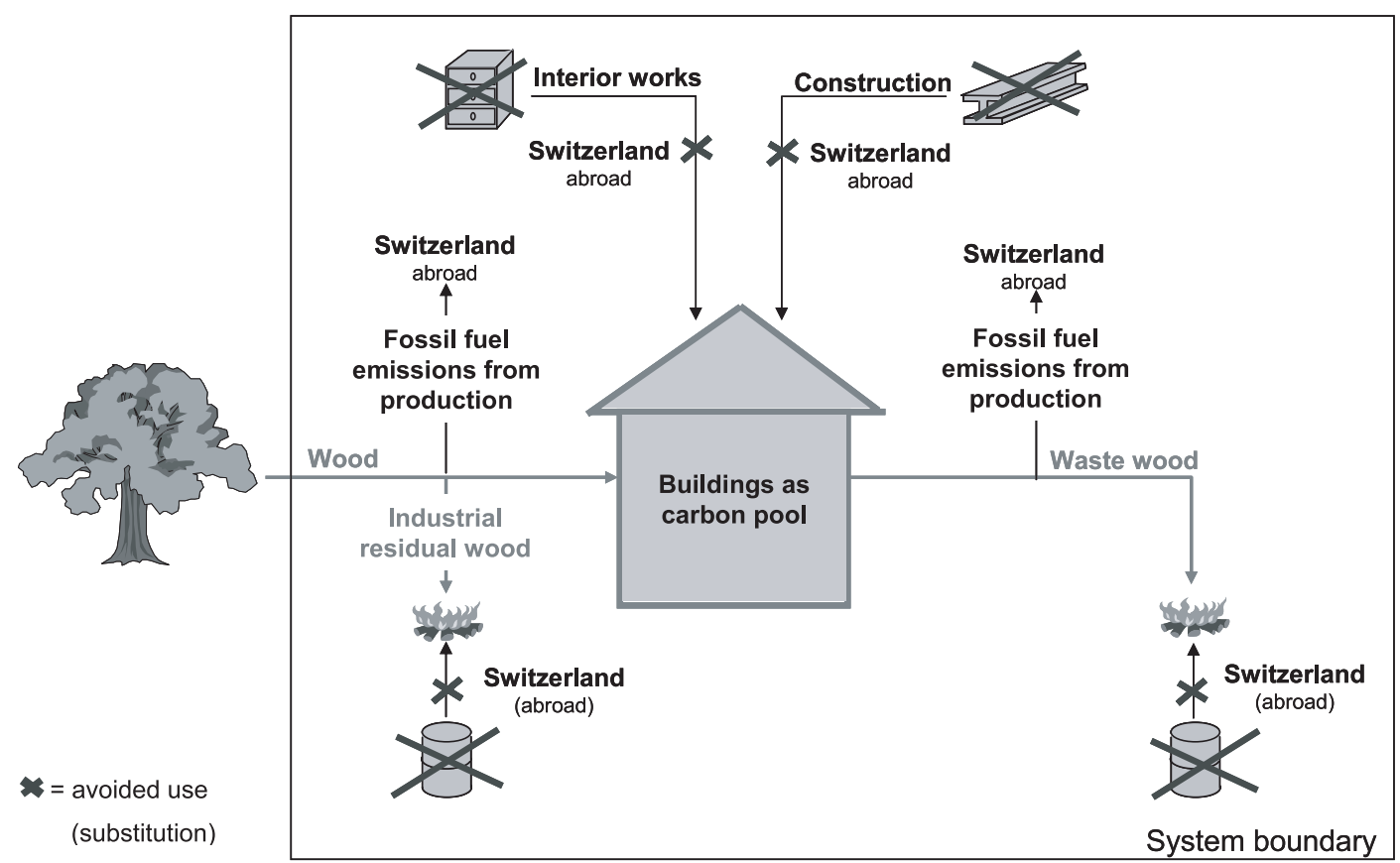

Figure 1. System boundaries of the building stock and its respective GHG effects.

\section{INTRODUCTION}

Wood as a $\mathrm{CO}_{2}$-neutral natural resource and energy carrier plays an important role in the discussion on the mitigation of climate change. Long-living wood products in particular can contribute to the mitigation of climate change in many ways [6, $13,15,25,26,30,31,34]$. On the one hand, wood products with long service life act as a carbon pool during their lifetime, as they withdraw $\mathrm{CO}_{2}$ from its natural cycle. After service life, they can substitute for fossil fuels if they are incinerated in adequate installations; on the other hand, wood products can substitute for more energy intense products made out of 'conventional' materials.

The Swiss Federal Council and the Swiss Parliament have committed to an active climate policy by signing and ratifying the Kyoto protocol. Knowledge about the effectiveness of measures to mitigate climate change is an important basis to achieve this commitment.

Much work has been done on international level to develop an adequate procedure for the accounting of long-living wood products in national greenhouse gas $(\mathrm{GHG})$ inventories $[4,9$, 14, 22, 29-32, 43]. Only estimates exist about the relevance of an increased use of wood products and the different ways this increased use impacts climate change [25].

The study emphasises the increased use of wood in the building sector, as this usage induces the most significant GHG effects compared to the GHG flows related to the use of paper or other wooden products [10]. The calculations are based on a 'realistic' scenario of future wood consumption in the building sector in Switzerland. For the calculations of the productgroup-specific GHG effects, life cycle data on GHG emissions of 12 wood products and their functionally equivalent substi- tutes is used as proxies for the most important groups of building products used for construction and for interior works. This data is linked to the forecasted wood flows for each group of building products in a cohort-model on a spreadsheet basis.

The model accounts for carbon flows when they occur in time. As no wood flows are crossing national frontiers, the discussion of different accounting principles (stock-change, atmospheric flow or production approach) is obsolete [36].

The investigation concentrates on the product-specific effects within technosphere, where especially the substitution effects are hardly quantified [25]; it disregards the well-investigated carbon cycle in the forest (see, e.g., [17, 23, 25, 33, 35]). Nonetheless, some theses are presented about the relationship between the two pools forest and long-living wood products. Further, the results of this study will be used in a further research project where the data of the two subsystems will be combined to depict the GHG effects of the complete wood chain.

\section{MODEL STRUCTURE, DATA, ASSUMPTIONS}

\subsection{System boundaries}

Figure 1 illustrates the investigated system with its GHG effects. It covers the building stock as a carbon pool, production and disposal emissions of 'fossil' $\mathrm{CO}_{2}$, substitution effects when substituting for 'conventional' products in the construction or interior works, and the energetic substitution effects of a consequent energetic use of residual and (post-consumer) waste wood.

For the political assessment, GHG effects occurring abroad and GHG effects in Switzerland are distinguished. 


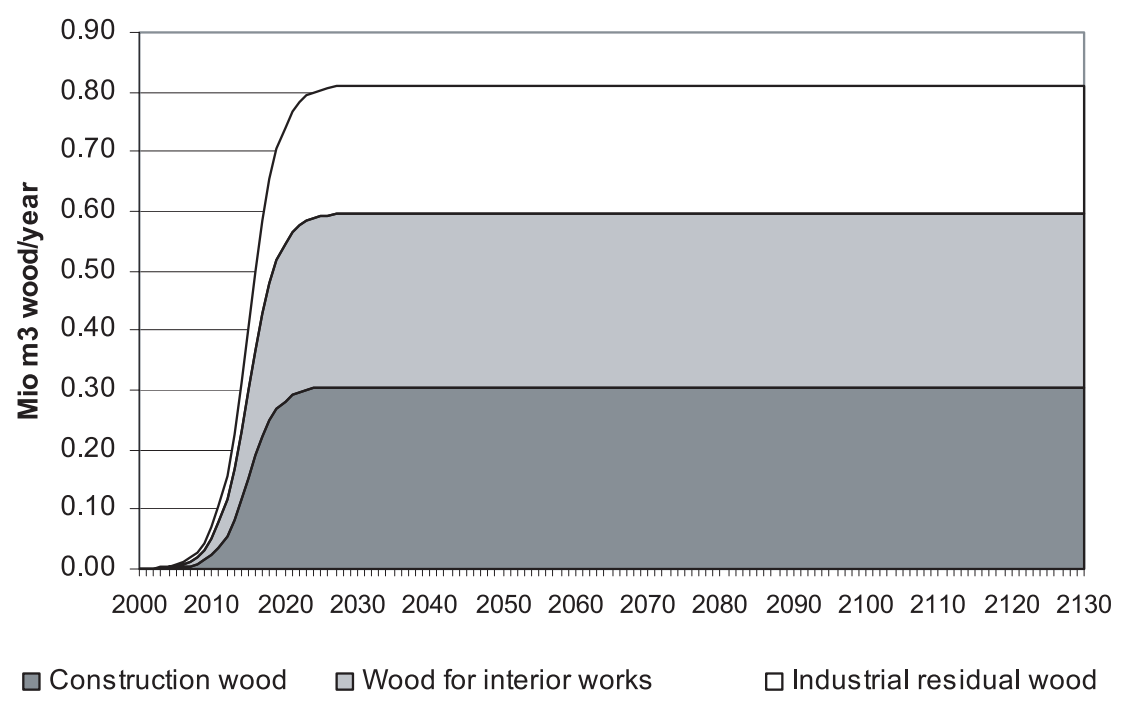

Figure 2. Increased use of wood flows in the years 2000 to 2130.

Table I. Assumed wood flows in the year 2030.

\begin{tabular}{|c|c|c|c|c|c|c|}
\hline \multirow[t]{2}{*}{ Wood consumption } & \multicolumn{2}{|c|}{ Current use } & \multicolumn{2}{|c|}{ Optimistic scenario } & \multicolumn{2}{|c|}{ Differences } \\
\hline & $\begin{array}{l}\text { Total quantity } \\
\left(\text { Mio. } \mathrm{m}^{3}\right)\end{array}$ & $\begin{array}{l}\text { Quantity per capita } \\
\text { (kg/cap. per y.) }\end{array}$ & $\begin{array}{l}\text { Total quantity } \\
\left(\text { Mio. } \mathrm{m}^{3}\right)\end{array}$ & $\begin{array}{l}\text { Quantity per capita } \\
\text { (kg/cap. per y.) }\end{array}$ & $\begin{array}{l}\text { Total quantity } \\
\left(\text { Mio. } \mathrm{m}^{3}\right)\end{array}$ & $\begin{array}{l}\text { Quantity per capita } \\
\text { (kg/cap. per y.) }\end{array}$ \\
\hline Construction wood & 1.05 & 75 & 1.36 & 97 & 0.31 & 22 \\
\hline Wood for interior works & 0.77 & 55 & 1.06 & 76 & 0.29 & 21 \\
\hline Residual wood & 0.91 & 65 & 1.12 & 80 & 0.21 & 15 \\
\hline Total & 2.73 & 195.0 & 3.54 & 253 & 0.81 & 58 \\
\hline
\end{tabular}

A time frame from the year 2000 until 2130 is looked at, as only shortly before the year 2130 , the wood flows will be in a steady state flow equilibrium and no more additional carbon will be stored.

\subsection{Scenario development of the future use of wood}

The modelling of the consequences of a future increased use of wood in the building sector is based on the following assumptions:

- Growth rate of the building sector economy of $1 \%$ per year;

- Increase of the market share of wood products of $2 \%$ every 10 years;

- Constantly high use of wood of +0.81 Mio. $\mathrm{m}^{3}$ additional wood after the year 2030;

- Logistic growth curve of the annual wood flows to show a more realistic behaviour.

Calculations are based on an average wood density of $500 \mathrm{~kg} / \mathrm{m}^{3}$ and a carbon content of $50 \%$.

Table I shows the wood use in the year 2030 that results from the above assumptions compared to the current wood use. Total annual wood consumption in constructions and buildings rises from $2.73 \mathrm{Mio.} \mathrm{m}^{3 /}$

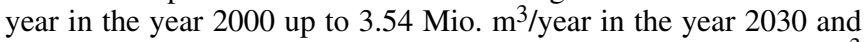
onward. This means an increased wood consumption of $0.81 \mathrm{Mio} . \mathrm{m}^{3}$ or $+12.5 \%$ compared to the wood consumption in the year 2000 .

Figure 2 illustrates the increased use of wood for the years 2000 to 2130 , cumulating construction wood, wood for interior works and industrial residual wood, which is caused during industrial wood processing. These wood quantities are attributed to the most relevant building elements such as roofs, exterior walls, interior walls, ceilings, floorings, etc. based on a Swiss market study on the current wood application potential in buildings [3]. Table II shows the distribution of the 0.81 Mio. $\mathrm{m}^{3}$ to the different wood products. For the years between 2000 and 2030, the input wood is distributed to the different wood products according to this relative share stated in Table II.

With these wood quantities, the potential for wood used for roofing or for furnishing is almost reached with a market share of about $80 \%$ (own calculations based on [3]).

Figure 3 shows the respective cumulated waste wood flows, assuming an average service life of 80 years for constructive wood products and 25 years for wood used for interior works.

For the modelling, no distinction is made between domestic and foreign wood. Thus, it is interesting to see if Swiss forests would be able to supply the required wood quantities. According to the National Inventory of Forests [2], annual growth lies around $10 \mathrm{Mio.}^{3}$ of wood. About $3 / 4$ or 7.5 Mio. $\mathrm{m}^{3}$ are considered as usable wood. If one compares the actual and projected future wood consumption, Swiss forests would thus be able to satisfy the additional wood demand without any imports ([11] based on [2]).

\subsection{Life cycle data as the basis of the substitution calculations}

Substitution is considered as the use of wood products instead of 'conventional' (solid) building products or fossil fuels. 


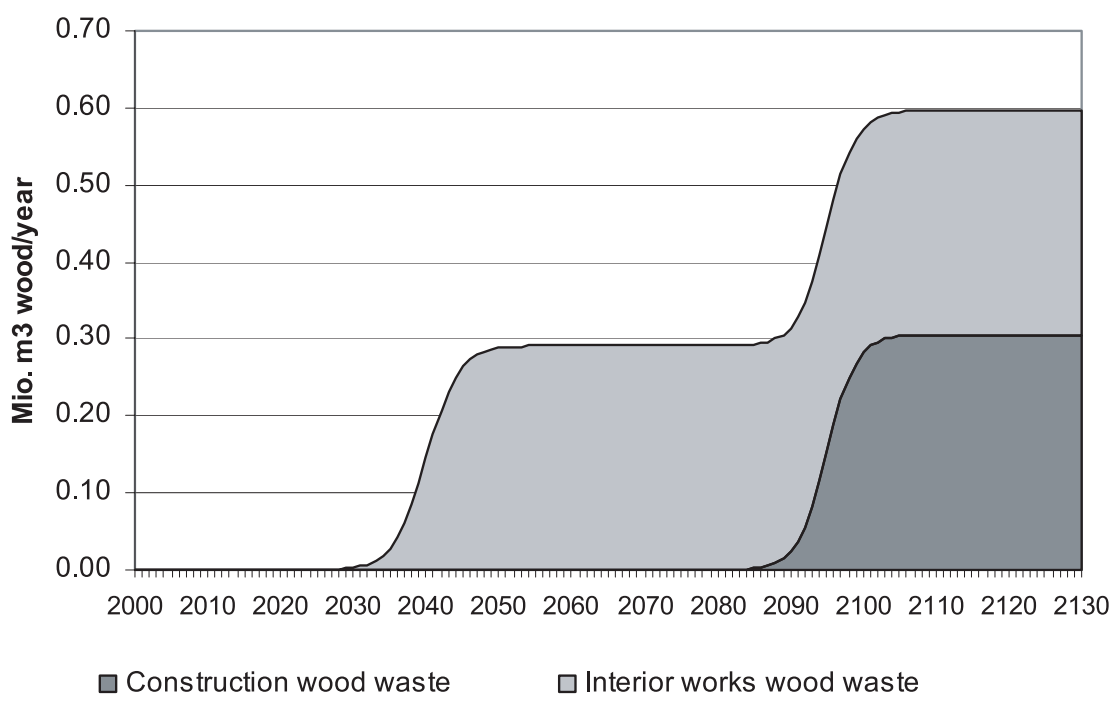

Figure 3. Increased waste wood flows in the years 2000 to 2130.

Table II. Distribution of the 0.81 Mio. $\mathrm{m}^{3}$ additional wood to the different wood products, including residual wood.

\begin{tabular}{lccc}
\hline Construction & $\mathrm{m}^{3}$ & Interior works & $\mathrm{m}^{3}$ \\
\hline Laminated timber board & 70298 & Profiled board spruce & 92868 \\
Gluelam pillar & 1054 & Staircase oak & 2955 \\
Ceiling out of wooden beams & 154145 & 3-layered parquet & 62989 \\
Wood fiber insulation panel & 10783 & Wood panels, rough, + supporting bars & 37382 \\
Unlined joist construction & 53275 & Doorframe, particleboard & 52322 \\
Wood palisade & 15423 & Furniture, particleboard & 33930 \\
& & Total construction & 304977 \\
& & Total interior works & 282446 \\
& & Residual wood & 222577 \\
\end{tabular}

For the determination of products that will be affected by an increased use of wood, assumptions must be made on the substitution mechanism. Different substitution mechanisms are conceivable and can depend on the type of decision maker, the type of building or the type of intervention (new construction, renovation, etc.) [11]. For this study, the results of an extensive survey on wood and its applicability in buildings among builder-owners, architects and engineers are used to determine the 'conventional' products to be substituted for [27, 41, 42]. Table III provides an overview of the substituting products.

For the determination of the GHG emissions associated with production, use and disposal of the above-mentioned products, data generated by Life Cycle Assessment (LCA) according to the series of standards ISO 14040ff is used [12] based on [18-21, 28, 37-40]. In comparative LCA, all life cycle stages of the competing products from raw material extraction, production to their use phase and disposal are accounted for and assessed, including energy generation and transports.

The GHG effects are indicated in $\mathrm{CO}_{2}$-equivalent. This means that all GHG emissions are weighted by the greenhouse gas potential in relation to $\mathrm{CO}_{2}$ [13]. For the products made out of wood, the $\mathrm{CO}_{2}$ sequestered during photosynthesis enters the calculations as a negative data. This $\mathrm{CO}_{2}$ is released again during incineration or biological decomposition at the end of the product life cycle.

It is assumed that by using an additional wood product, the production, use and disposal of a substitute is avoided (- substitute + wood product). A negative sign means that by using a wood product instead of its substitute, GHG emissions are avoided; a positive sign indicates that the (fossil) GHG emissions during the life cycle of the wood product are higher than the ones of the substitute (for product-specific data, see Annex).

For the determination of the substitution effect, the current import/ export shares are taken into account [12].

The above-mentioned calculations are rather sensitive with regard to several assumptions: (a) the selected wood product representing a group of similar wood products, (b) the selected substitute representing a group of similar 'conventional' products, (c) the assumption that exactly this 'conventional' product substitutes for wood products, and (d) the system boundaries and allocation procedures used in the individual LCAs [19, 20, 38-40]. Nonetheless, attention was paid that the compared products are functionally equivalent and have the same service life. 


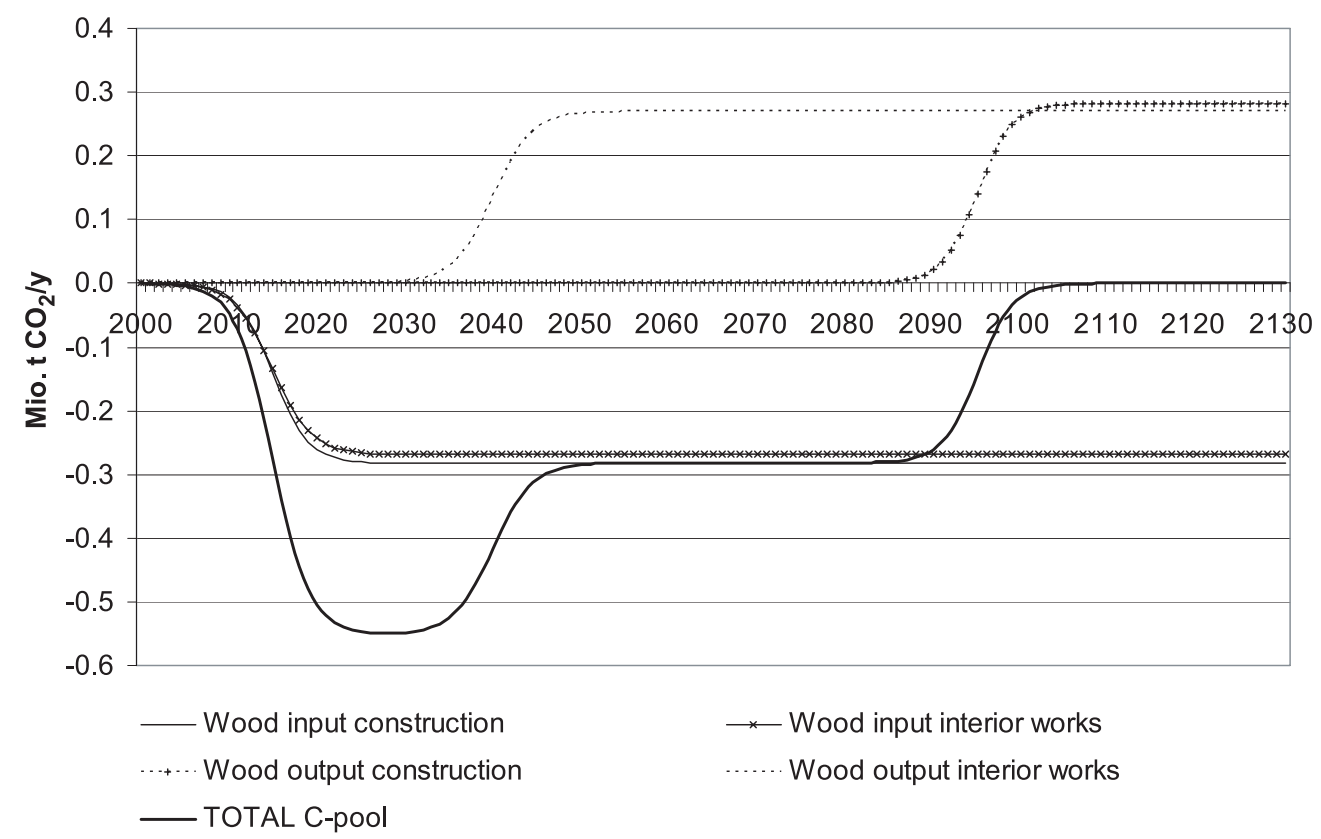

Figure 4. Dynamics of the building stock as carbon pool 2000 to 2130 (annual flows).

Table III. Overview on the building products made out of wood and their substitutes.

\begin{tabular}{|c|c|c|}
\hline Building element & Wood elements/products & Competing product/substitute \\
\hline \multicolumn{3}{|l|}{ Construction } \\
\hline Exterior wall & Laminated timber board & 2-layered brick wall \\
\hline Pillar & Gluelam pillar & Steel pillar \\
\hline Ceiling & Ceiling of wood beams & Ceiling of reinforced concrete \\
\hline Insulation & Wood fibre insulation panel ${ }^{1}$ & Mineral wool $^{2}$ \\
\hline Roofing & Unlined joist construction & Porous concrete pitched roof \\
\hline Underground engineering & Wood palisade & Concrete palisade \\
\hline \multicolumn{3}{|l|}{ Interior works } \\
\hline Coverings of ceilings and walls & Profiled board, spruce & Interior plasterwork \\
\hline Staircase & Wooden staircase, oak & Ready-made concrete staircase \\
\hline Flooring & 3-layered parquet flooring & Ceramic tiles, enamelled \\
\hline Facade & Wood panels rough incl. supporting bars 1 & Exterior plasterwork ${ }^{2}$ \\
\hline Furnishing & Doorframe, particleboard & Doorframe, steel \\
\hline Furniture & Wood furniture, particleboard & Steel furniture \\
\hline
\end{tabular}

${ }^{1}$ In a laminated timber board construction.

2 In a 2-layered brick wall.

\section{RESULTING GHG DYNAMICS}

\subsection{Long-living wood products as carbon pool}

If the wood pool in the building stock is enlarged, the carbon pool is enlarged.

The average service life of construction wood of 80 years is assumed. This implies that with an increase of wood consump- tion until the year 2030, the wood pool in buildings will have reached a steady state flow equilibrium in the year 2110 . From then on, the annual wood input is equal to the wood output. The dynamics of the building stock as C-pool due to an increased use of wood are illustrated in Figure 4.

According to the assumed development of an increased use of wood, an enlargement of the carbon pool takes place from the year 2010 to the year 2030 ( $-0.55 \mathrm{Mio}$. $\mathrm{CO}_{2}$ /year as a maximum). 


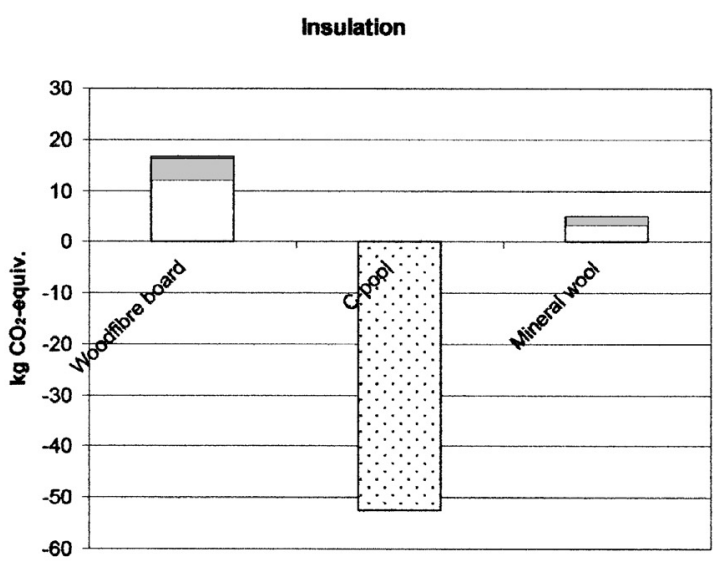

Exterior wall

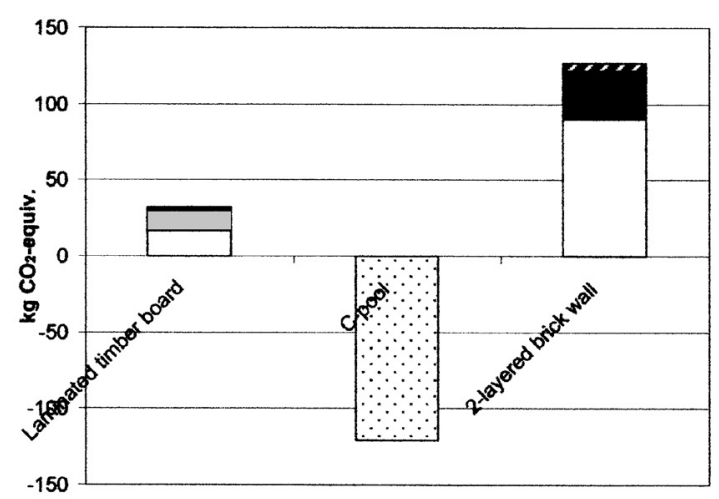

$\square$ Production $\mathrm{CH} \quad \square$ Produktion abroad

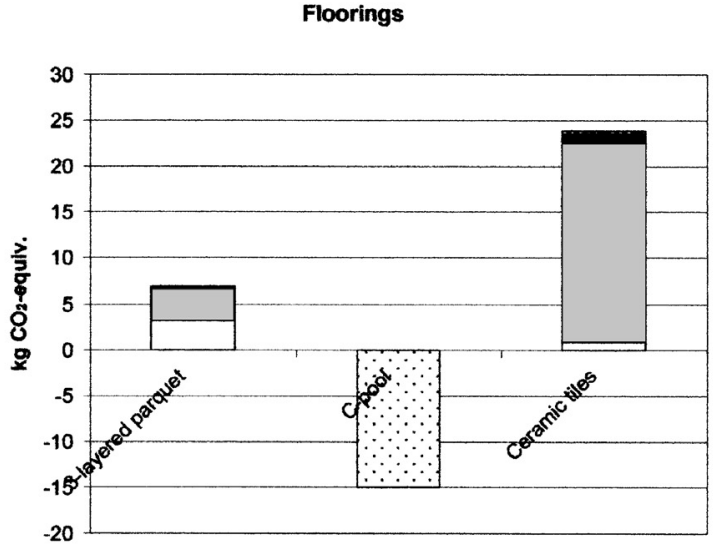

Doorframe

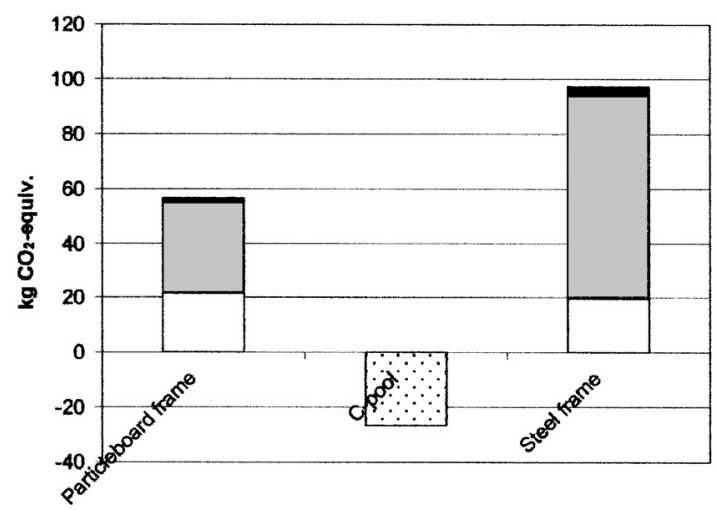

Disposal $\mathrm{CH}$

\section{Disposal abroad}

Figure 5. Selected product-specific potential carbon pool capacities, production emissions and substitution effects, in Switzerland (CH) and abroad.

From then on, the thermal use of the first products of interior works at the end of their service life reduces the annual enlargement of the C-pool. From the year 2050 onward, the annual enlargement stabilises at $-0.28 \mathrm{Mio}$. $\mathrm{CO}_{2}$ /year until the moment when the thermal use of the additionally used construction wood starts. From the year 2110 onward, the wood outputs equal the wood inputs to the system: inputs and outputs are in a steady-state flow equilibrium. As a consequence, no more carbon is additionally stored. The wood pool stabilises at $-30 \mathrm{Mio}$. $\mathrm{CO}_{2}$, which corresponds to an additional wood volume of $32 \mathrm{Mio.} \mathrm{m}^{3}$ in the building stock. This carbon pool potential corresponds to about $60 \%$ of the GHG emissions of Switzerland in one year; this potential will be reached by the year 2110 .

\subsection{Production emissions and substitution effects}

The relation between production emissions, the possible $\mathrm{C}$ pool effect and possible substitution effects are product-dependent, as Figure 5 shows on an exemplary basis (for detailed data, see Annex).
Figure 5 demonstrates that the (fossil) GHG emissions related to production and disposal can surpass the carbon content of a finished wood product (example doorframes), but can also be considerably lower. Generally, the fossil GHG emissions from disposal are neglectable compared to the production emissions, except the ones for solid exterior walls (weight!).

The production and disposal emissions of 'conventional' products tend to be higher than the ones caused by wood products $[1,13]$; the exception of the insulation material confirms this rule.

Also the locations of the relevant GHG emissions can differ. If 'conventional' products are produced abroad, an additional wood consumption in Switzerland will increase the national GHG inventory, as emissions occurring abroad will be substituted for (example floorings). A similar mechanism can be observed with the products for interior works, as 'conventional' products are often made of GHG-intense but imported steel; the associated emissions in Switzerland are relatively low. For construction materials on the contrary, the substitution for generally GHG-intense, heavy and thus nationally produced, 


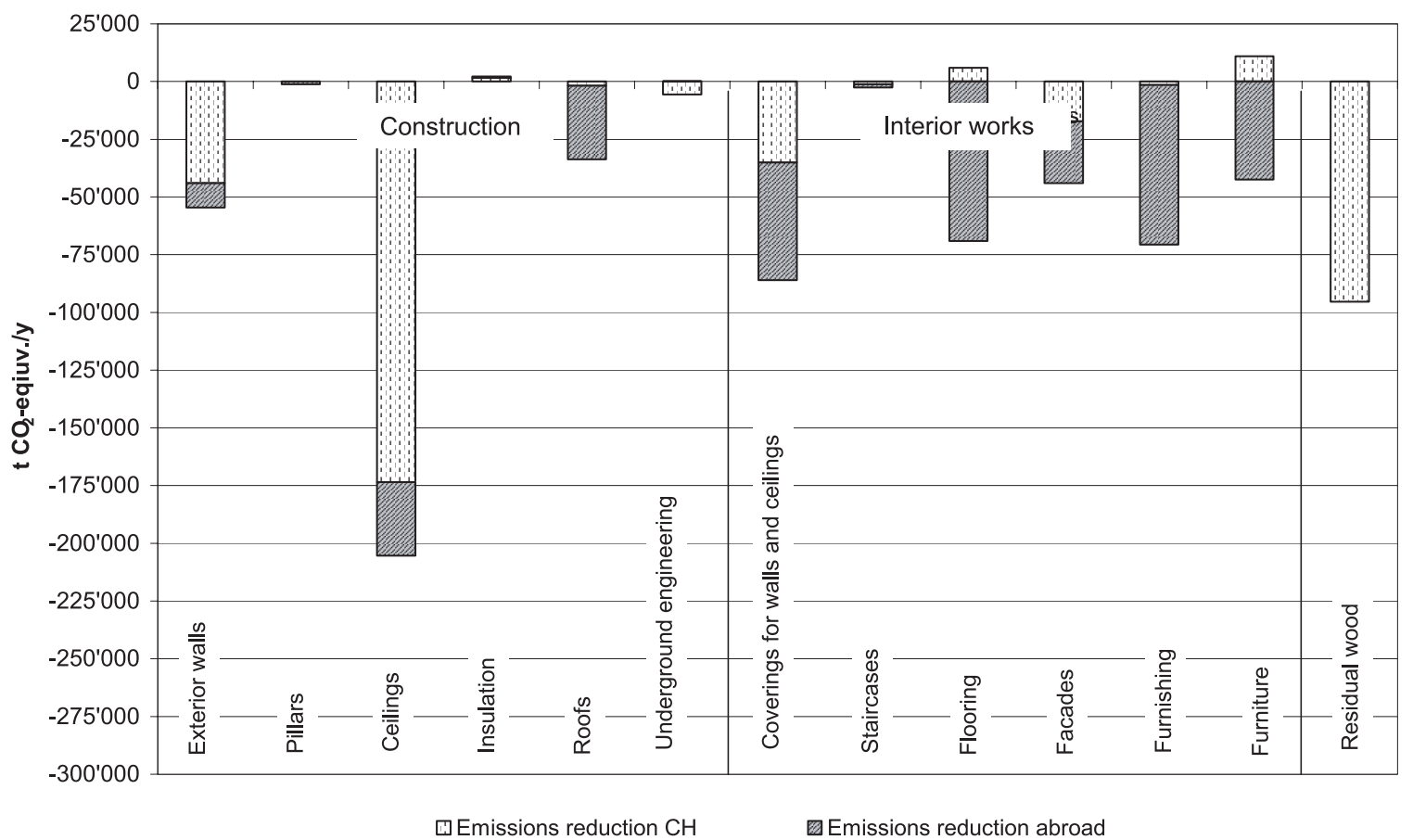

Figure 6. Substitution effects of different wood products due to an increased use of wood, in Switzerland $(\mathrm{CH})$ and abroad $\left(+0.81 \mathrm{Mio}^{3} \mathrm{~m}^{3}\right.$ of wood).

Table IV. GHG emissions related to wood product production and disposal, and substitution effects related to an increased use of wood of 0.81 Mio. $\mathrm{m}^{3} / \mathrm{year}$.

\begin{tabular}{|c|c|c|c|}
\hline \multicolumn{2}{|c|}{ Production emissions (+ disposal) } & \multicolumn{2}{|c|}{ Material substitution } \\
\hline $\begin{array}{c}\mathrm{CH} \\
\text { (Mio. } \mathrm{CO}_{2} \text {-equiv.) }\end{array}$ & $\begin{array}{c}\text { abroad } \\
\text { (Mio. } \mathrm{t} \mathrm{CO}_{2} \text {-equiv.) }\end{array}$ & $\begin{array}{c}\mathrm{CH} \\
\text { (Mio. } \mathrm{CO}_{2} \text {-equiv.) }\end{array}$ & $\begin{array}{c}\text { abroad } \\
\text { (Mio. } \mathrm{CO}_{2} \text {-equiv.) }\end{array}$ \\
\hline 0.152 & 0.166 & -0.261 & -0.335 \\
\hline
\end{tabular}

'conventional' products of concrete or bricks will lead to a reduction of the GHG emissions in Switzerland.

Figure 6 illustrates that an increased use of wood for ceilings will develop the highest substitution effects in a global perspective as well as in Switzerland. Given the currently low market share, wooden ceilings constitute a high potential for a GHG reducing use of wood. Further, a consequent and efficient thermal use of the additional residual wood in suited adequate furnaces to substitute for fossil fuels is of utmost importance.

This result confirms the insight gained during the productspecific considerations: the substitution of GHG-intense 'conventional' (semi-finished) products for interior works provides a considerable GHG effect but the emissions are mainly substituted abroad. Contrary to that, the substitution of 'conventional' construction products provides a certain GHG emissions reduction potential in Switzerland, besides the ceilings also for exterior wood walls. Table IV gives a summary of the production and disposal emissions as well as of the substitution effects of an increased use of wood of $0.81 \mathrm{Mio.} \mathrm{m}^{3} /$ year.

\subsection{Energetic substitution effects}

The substitution capacity described in the previous section does not take into account the thermal utilisation of the residual and post-consumer waste wood. To calculate this effect, two $100 \mathrm{~kW}$ incineration facilities fired with fuel oil and logs are compared. The difference shown in Table V is used to calculate the energetic substitution effects of an increased use of wood.

Around 0.21 Mio. $\mathrm{m}^{3} /$ year of the additionally used $0.81 \mathrm{Mio}$. $\mathrm{m}^{3} /$ year wood (from the year 2030 onward) end up as industrial residual wood and are used for the production of thermal energy. According to the calculations based on Table $\mathrm{V}$, about 0.096 Mio. $\mathrm{t} \mathrm{CO}_{2}$-equiv./year can be avoided because of the substitution of fossil fuels with the additional residual wood.

The remaining $0.6 \mathrm{Mio} . \mathrm{m}^{3} /$ year or $300000 \mathrm{t}$ of wood/year enter the building stock and can be used thermally at the end of the service life of the building elements. If all the wood that is additionally used in the building stock will be used thermally in specialised wood incinerators, an additional energetic substitution effect of 0.265 Mio. $\mathrm{t} \mathrm{CO}_{2}$-equiv./year can be 


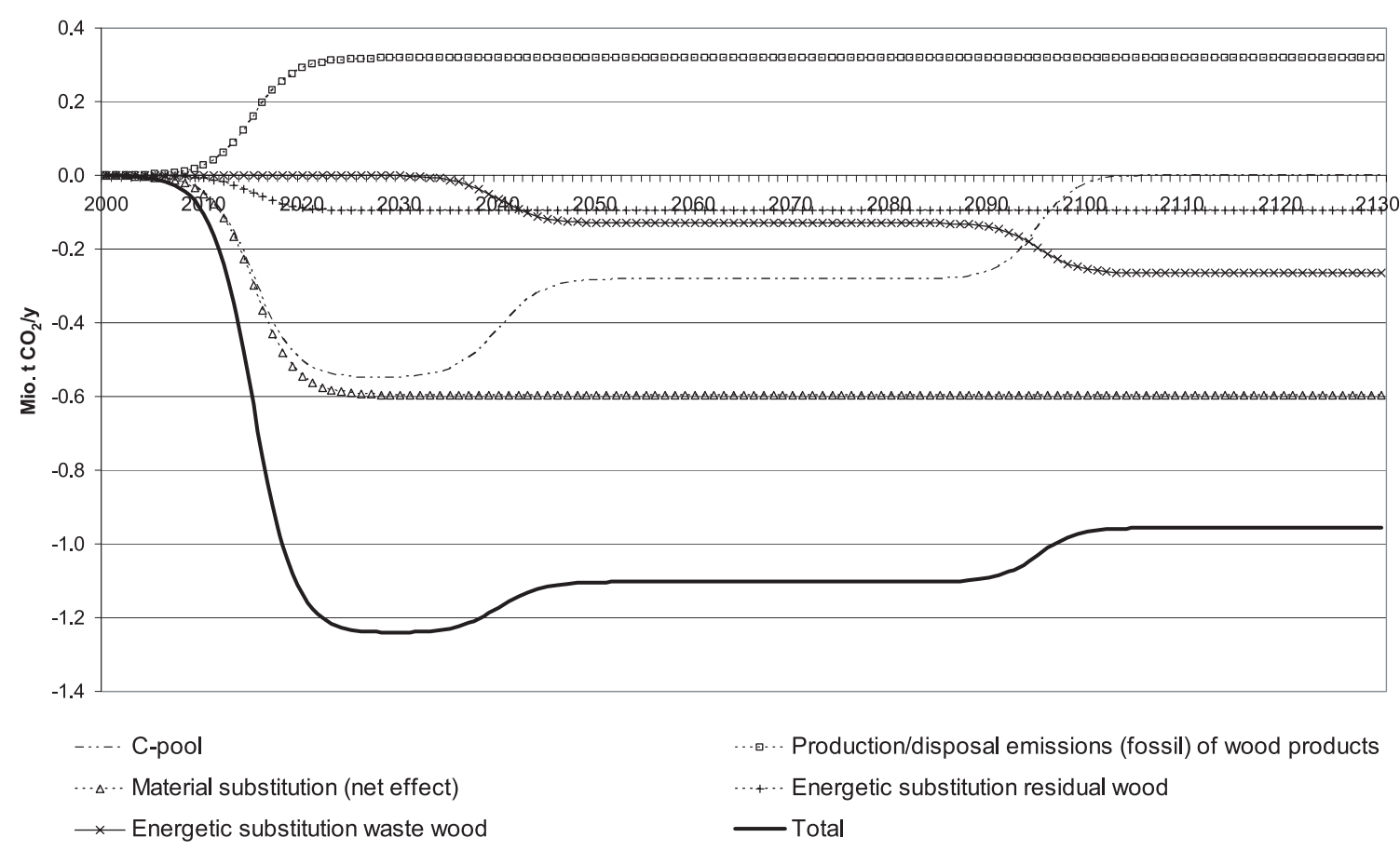

Figure 7. GHG emissions dynamics of an increased use of wood (2000-2130).

Table V. Fuel inputs and GHG emissions of different installations for the generation of 1 TJ usable energy (278 MWh) [8].

\begin{tabular}{lcccc}
\hline Fuel & $\begin{array}{c}\text { Size of the installation } \\
(\mathrm{kW})\end{array}$ & $\begin{array}{c}\text { Fuel quantity } \\
(\mathrm{kg})\end{array}$ & $\begin{array}{c}\text { Fossil GHG emissions } \\
\left(\mathrm{kg} \mathrm{CO}_{2} \text {-equiv. }\right)\end{array}$ & $\begin{array}{c}\text { Difference } \\
(\mathrm{kg} \mathrm{CO} \text {-equiv. })\end{array}$ \\
\hline Fuel oil & 100 & 27200 & 91100 & 88090 \\
Logs & 100 & 100000 & $3010^{1}$ & \\
\hline
\end{tabular}

${ }^{1}$ Emissions from chainsaws, transports, etc.

achieved. This substitution effect is composed of the incineration of the products used for interior works (after a service life of 25 years) as well as of the products used for construction (after a service life of 80 years).

In total and over the whole life cycle of the wood products, emission reductions of $0.36 \mathrm{Mio}$. $\mathrm{CO}_{2}$-equiv. can be achieved with a consequent and efficient thermal utilisation of the generated residual and post-consumer waste wood as consequence of an additional use of $0.81 \mathrm{Mio} . \mathrm{m}^{3}$ wood. In these calculations, a $\mathrm{CO}_{2}$-neutral decomposition (or incineration without energy recovery) of waste wood is assumed as the reference scenario; also avoided methane emissions or carbon storage effects in landfills of wood are disregarded, as the dumping of waste wood is prohibited in Switzerland.

\subsection{GHG emissions dynamics of an increased use of wood}

The GHG emissions dynamics of an increased use of wood are relatively complex, as different effects with different temporal dynamics overlap. Figure 7 summarises the effects of a steadily increased use of wood up to $0.81 \mathrm{Mio} . \mathrm{m}^{3} /$ year from the year 2030 onward (see Sect. 2.2).

Several points can be observed:

- The net GHG effects of the material substitution (emissions avoidance of 0.6 Mio. $\mathrm{t}_{2}$ ) are more important than the (fossil) GHG emissions related to the production and disposal of the wood products (emissions of $0.3 \mathrm{Mio} . \mathrm{t} \mathrm{CO}_{2}$ );

- The avoided (fossil) GHG emissions due to the thermal use of construction waste wood become more important than the thermal use of residual wood as soon as the thermal use of the construction waste wood reaches a constant level (2050);

- The substitution of fossil fuels as a consequence of the thermal use of residual and waste wood as well as the effects of the material substitution compensate by far the (fossil) GHG emissions from the production and disposal of the wood products. They are also more important than the effect on the carbon pool, especially on long-term (this reconfirms findings of $[1,13,23])$;

- The stabilisation of the carbon pool is not compensated by the additional thermal use of waste wood and its substitution effect from the year 2090 onward; 


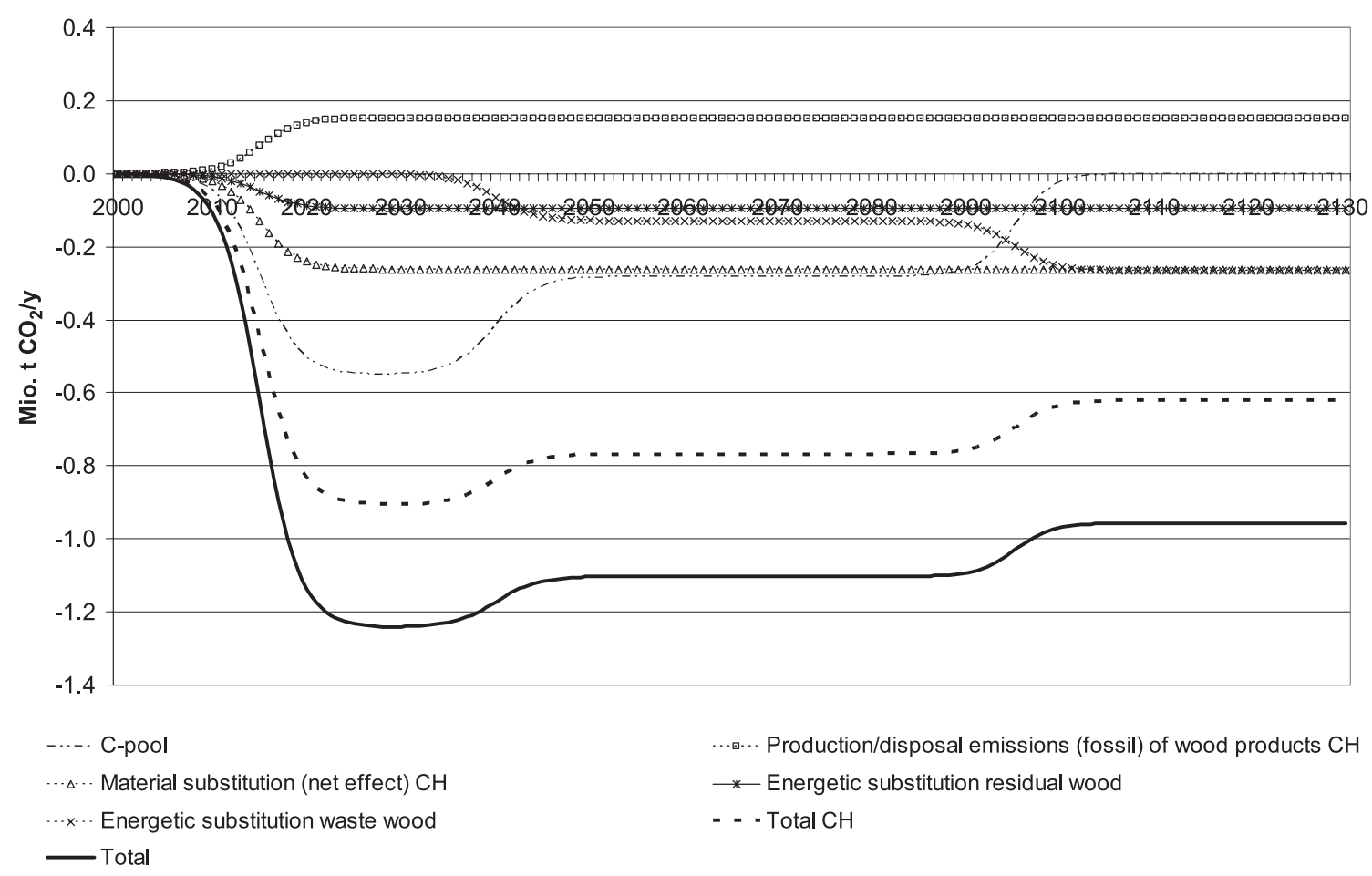

Figure 8. Annual GHG flows in Switzerland due to an increased use of wood (2000-2130).

- In the first years (2010 to the year 2035), the enlargement of the C-pool contributes around $60 \%$ to the total GHG effect. The relative contribution of the C-pool diminishes over the years from the year 2030 onward;

- The largest GHG effect over the shortest time will be reached until the year 2020 .

\subsection{Influence of Swiss national boundaries}

Political decisions to increase the use of wood are made on national level, as well as the inventorisation of the GHG emissions of Switzerland. Thus, the GHG effects of an increased use of wood within Switzerland are of particular interest. The contributions of the different GHG-relevant mechanisms of an increased use of wood over time are depicted in Figure 8 (see also Fig. 7 for comparison).

Figure 9 illustrates the cumulated GHG flows for the same period.

One can conclude that:

- The mayor part of the GHG effect as a consequence of an increased use of wood occurs in Switzerland;

- The dynamics of the GHG emissions in Switzerland correspond to the dynamics of the total flows (see Fig. 9);

- In the steady state flow equilibrium (in the year 2110), the thermal use of waste wood is as relevant as the material substitution in Switzerland;

- During the first years, the fossil production emissions of the wood products are smaller than the C-pool effect; the rele- vance of the C-pool effect decreases in later years compared to the steadily increasing cumulated production emissions as well as compared to the total GHG effect;

- A consequent and efficient use of post-consumer waste wood in adequate incinerators is a key strategy for the mitigation of the GHG relevance of Switzerland - given the relation of residual wood and waste wood flows even more relevant than the thermal use of the residual wood.

An in-depth analysis of the (fossil) GHG emissions related to production and disposal as of the effects of the material substitution reveals that:

- About the same amount of GHG emissions related to production and disposal is released abroad and in Switzerland;

- The effect of the material substitution abroad corresponds more or less to the GHG effect achieved in Switzerland.

As one can see in the above figures, the relevance of the described effects changes over time. Table VI summarises the cumulated effects as well as their relative share of the total GHG effect in Switzerland for some (politically relevant) years.

Note for the interpretation of this table that emissions stated for earlier years cannot be added up with the stated emissions from later periods (cumulative data). The tendencies of the relative importance of single effects compared to the over-all effect in Switzerland can easily be figured out by looking at the percentages in a horizontal way.

Particular political relevance has the data for the year 2012, as this is the final year of the first commitment period of the Kyoto protocol. The relevance of the C-pool with a contribution 


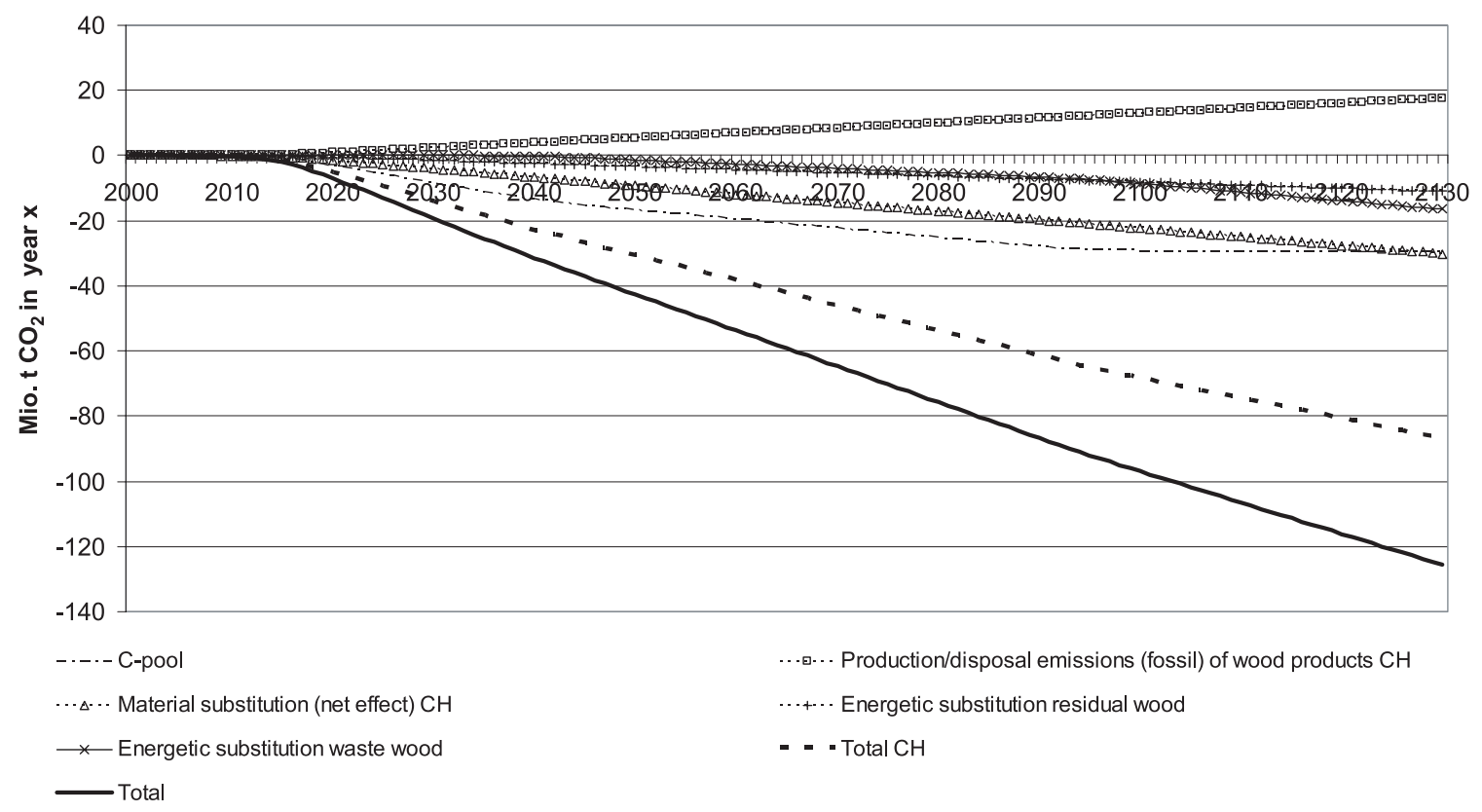

Figure 9. Cumulated GHG effects of an increased use of wood in Switzerland (2000-2130).

Table VI. Cumulated GHG effect and relative share of the total GHG effect of an increased use of wood in Switzerland.

\begin{tabular}{|c|c|c|c|c|c|c|c|}
\hline Year & $\left(\right.$ Mio. t $\left.\mathrm{CO}_{2}\right)$ & $\begin{array}{l}\text { Production emissions } \\
\text { of wood products } \\
\text { (fossil) } \mathrm{CH} \\
\left(\text { Mio. } \mathrm{CO}_{2}\right)\end{array}$ & $\begin{array}{l}\text { Material substitution } \\
\text { (net effect) } \mathrm{CH} \\
\left(\text { Mio. } \mathrm{CO}_{2}\right)\end{array}$ & $\begin{array}{l}\text { Energetic substitution } \\
\text { residual wood } \\
\quad\left(\text { Mio. } \mathrm{CO}_{2}\right)\end{array}$ & $\begin{array}{l}\text { Energetic substitution } \\
\text { waste wood } \\
\left.\quad \text { (Mio. } \mathrm{CO}_{2}\right)\end{array}$ & (Mio. t $\mathrm{CO}_{2}$ ) & (Mio. $\left.\mathrm{tCO}_{2}\right)$ \\
\hline 2000 & 0.00 & 0.00 & 0.00 & 0.00 & 0.00 & 0.00 & 0.00 \\
\hline \multirow[t]{2}{*}{2010} & -0.13 & 0.04 & -0.05 & -0.02 & 0.00 & -0.20 & -0.29 \\
\hline & $62.5 \%$ & $-17.2 \%$ & $26.7 \%$ & $10.8 \%$ & $0.0 \%$ & $100.0 \%$ & $141.0 \%$ \\
\hline \multirow[t]{2}{*}{2012} & -0.31 & 0.08 & -0.14 & -0.05 & 0.00 & -0.49 & -0.69 \\
\hline & $61.9 \%$ & $-17.1 \%$ & $27.4 \%$ & $10.7 \%$ & $0.0 \%$ & $100.0 \%$ & $139.7 \%$ \\
\hline \multirow[t]{2}{*}{2030} & -8.54 & 2.36 & -4.05 & -1.48 & 0.00 & -14.08 & -19.26 \\
\hline & $60.7 \%$ & $-16.8 \%$ & $28.8 \%$ & $10.5 \%$ & $0.0 \%$ & $100.0 \%$ & $136.9 \%$ \\
\hline \multirow[t]{2}{*}{2050} & -16.73 & 5.40 & -9.28 & -3.39 & -1.36 & -30.77 & -42.64 \\
\hline & $54.4 \%$ & $-17.6 \%$ & $30.2 \%$ & $11.0 \%$ & $4.4 \%$ & $100.0 \%$ & $138.6 \%$ \\
\hline \multirow[t]{2}{*}{2100} & -29.25 & 13.00 & -22.34 & -8.16 & -8.60 & -68.36 & -96.96 \\
\hline & $42.8 \%$ & $-19.0 \%$ & $32.7 \%$ & $11.9 \%$ & $12.6 \%$ & $100.0 \%$ & $141.8 \%$ \\
\hline \multirow[t]{2}{*}{2130} & -29.28 & 17.56 & -30.18 & -11.03 & -16.54 & -87.03 & -125.67 \\
\hline & $33.7 \%$ & $-20.2 \%$ & $34.7 \%$ & $12.7 \%$ & $19.0 \%$ & $100.0 \%$ & $144.4 \%$ \\
\hline
\end{tabular}

of $-62 \%$ of the total effect in Switzerland is particularly noteworthy, followed by the net effect of the material substitution with a relative effect of $-27 \%$. Of lower importance at this point in time is the effect of the thermal use of residual wood with $-11 \%$; post-consumer waste wood of the increased use of wood is still not available at that moment. These 'positive' effects go along with product emissions of around $18 \%$ of the total effect of an increased use of wood in Switzerland.
If one considers the effect of an increased use of wood in the mirror of the reduction commitment in absolute terms, the following picture arise. Assuming annual national average GHG emissions of around 53 Mio. $\mathrm{t} \mathrm{CO}_{2}$-equivalents, the reduction commitment of $8 \%$ over 5 years adds up to around 21 Mio. $\mathrm{t} \mathrm{CO}_{2}$-equivalents. If this data is compared with the cumulated effect of an increased use of wood for the years 2008-2012, the total effect of 0.49 Mio. $\mathrm{t} \mathrm{CO}_{2}$ is equivalent of 


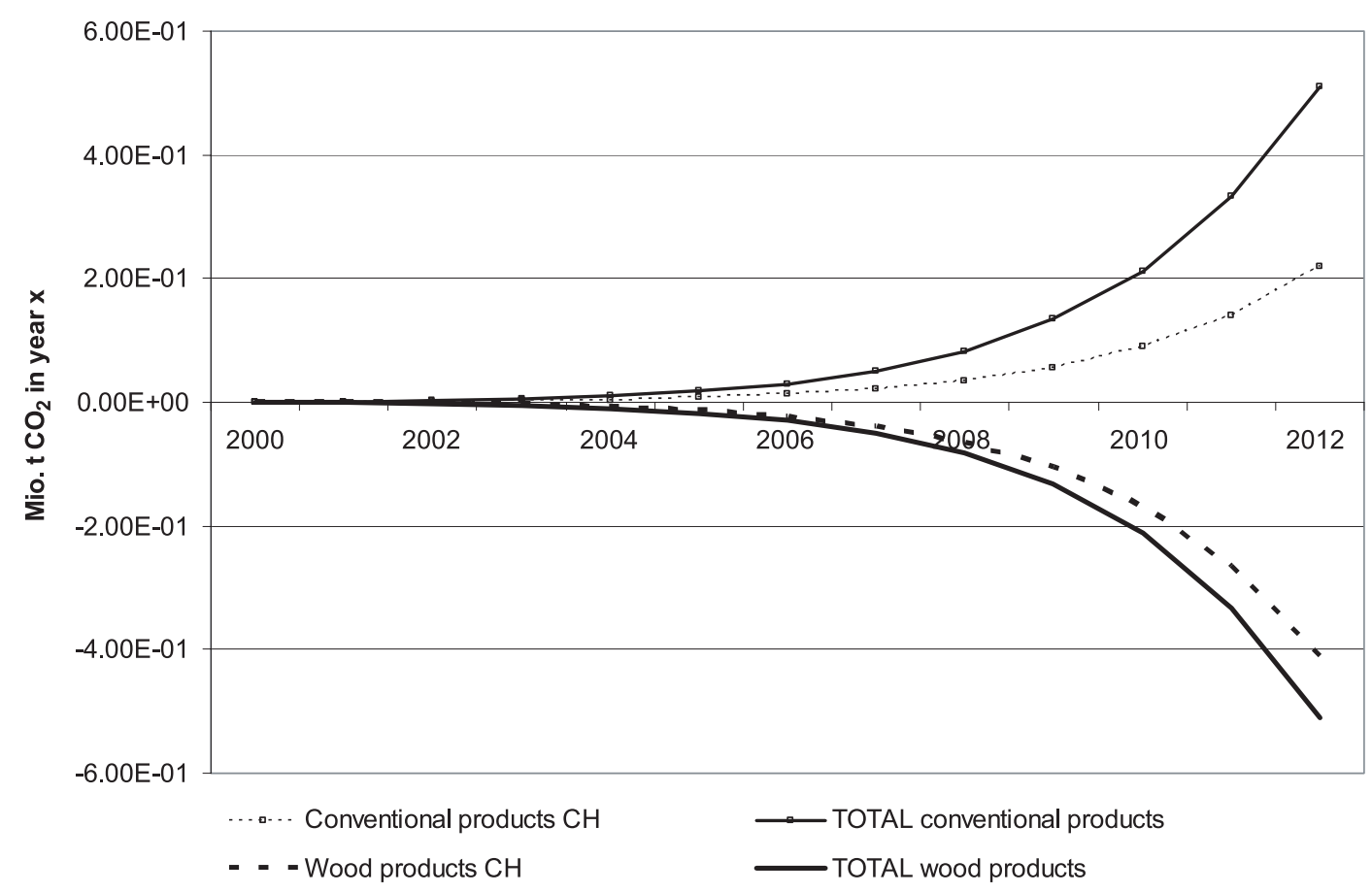

Figure 10. Scenario 'conventional' products instead of wood products 2000-2012 (cumulated flows).

about $2 \%$ of the reduction commitment. This low value is the consequence of the fact, that the increased use of wood starts to become significant not earlier than the year 2010; the greatest effect of this wood use scenario develops between 2020 and 2030 (Fig. 8).

This low relevance for the first commitment period should not be misinterpreted: an increased use of wood constitutes a reasonable measure to mitigate climate change - but only on a medium to long-term. This illustrates Figure 10, which shows how the GHG emissions of Switzerland would develop if the building elements were built of 'conventional' materials instead of wood.

In such a scenario, cumulated additional emissions of 0.22 Mio. $\mathrm{t} \mathrm{CO}_{2}$-equivalents in Switzerland related to the use of 'conventional' products are facing cumulated emissions reductions and $\mathrm{C}$-pool effects of around $-0.5 \mathrm{Mio}$. $\mathrm{CO}_{2}$-equivalents because of an increased use of wood.

\subsection{Theses on the interplay of forests and wood products as carbon pool}

The principal aim of the investigation described above is to investigate the importance and dynamics of different GHGrelated effects of an increased use of wood within technosphere. One important effect of an increased use of wood was neglected: the decline of the carbon storage in the forests because of an increased wood extraction.

This interplay will be investigated in a future project where these results will be coupled to an investigation of the GHG effects of different forest management practices. Nonetheless, some general considerations on the pool dynamics of forests and wood products should be presented here.

The success to enlarge the pool of long-living wood products in technosphere and to achieve a major GHG abatement effect will depend on various variables:

- Up to twice as much biomass will be cut in the forests compared to the wood quantities that enter the building stock (conifers about $+25 \%$ [1]). The forests will thus lose up to twice as much carbon than will be potentially stored in longliving wood products (excluding potential effects on the organic carbon soil content);

- The way in which the remaining wood is used will be a key factor with regard to the source effect of cutting trees. Substituting for fossil fuels with the surplus organic material seems the most promising strategy from a climate change perspective $[1,5,24]$. Nonetheless, site productivity should not be affected [25];

- Mathematically, the results will depend much on the use of the forests in the scenario where only additional 'conventional' materials are used [1, 7, 16, 24];

- The over-all C-pool effect will basically depend on the ratio between the growth rate of new trees and the service life of products [6];

- Negative overall pool effects ('source' effects) cannot be excluded from an increased use of wood-at least in a short to medium-term. Still, the size of the energetic and material substitution effects will justify an increased use of wood in any case. 


\section{CONCLUSIONS}

An increased use of wood in the building sector can have relevant effects in terms of GHG emissions reductions on a medium term. Substitution effects related to the thermal use of residual and post-consumer waste wood as well as effects related to the substitution of wood products for products made of 'conventional' materials contribute the most to the over-all GHG effect. The C-pool effect due to the enlargement of the pool of wood products should not be overestimated and might in fact be rather low. This effect is linked to a far larger decrease of the standing volume of trees (and thus carbon) in the forests and of soil carbon because of the harvesting, an effect that is compensated only very slowly by the re-growth of the forest. Understanding the linkage between forest carbon pools and flows and the building carbon pools and flows in detail is an urgent research need.

Given the relative importance of the energetic substitution effects, it is not surprising to see that the mayor part of the GHG effects occur in Switzerland. Still, a Swiss national strategy to mitigate climate change by an increased use of wood products should target at wood products used for construction. Only for this group of wood products, the related material substitution effects occur within Switzerland, as energy-intense, locally produced, heavy products such as concrete or bricks are substituted for. On the contrary, wood products used for interior works mostly substitute for imported products such as steel or ceramic tile; the related substitution effect in Switzerland is low, or even negative.

Concluding, three key elements of a Swiss strategy to mitigate climate change by an increased use of wood in buildings are summarized:

1. Efficient and effective thermal use of residual and postconsumer waste wood to substitute for fossil fuels;

2. Increased use of wood in the construction;

3. Avoidance of collateral carbon emissions in the forests during harvesting (decrease of the carbon pool in trees and forest soil), i.e. the thermal utilisation of harvesting residues to substitute for fossil fuels.

Finally, it has to be stated that the GHG effects related to an increased use of wood in buildings are not sufficient to compensate the high GHG emissions in other sectors of the economy. Additional measures in those sectors - traffic for example - are necessary to meet the (future) Kyoto commitment of Switzerland.

Acknowledgements: We gratefully acknowledge the careful revisions of the manuscript by two anonymous reviewers.

\section{REFERENCES}

[1] Börjesson P., Gustavsson L., Greenhouse gas balances in building construction: wood versus concrete from life-cycle and forest landuse perspectives, Energy Policy 28 (2000) 575-588.

[2] Brassel P., Brändli U.B., Swiss national forest inventory; results of the second sampling 1993-1995, Haupt, Bern, Stuttgart, Wien, 1999 (in German).
[3] BUWAL, Final consumption of wood in Switzerland 1996, Bundesamt für Umwelt, Wald und Landschaft (BUWAL), Bern, 1996 (in German).

[4] Dias A.C., Louro M., Arroja L., Capela I., The contribution of wood products to carbon sequestration in Portugal, Ann. For. Sci. 62 (2005) 903-909.

[5] Eldag H., Wood and wood products, in: Altenpohl D.G. (Ed.), Materials in world perspective; assessment of resources, technologies and trends for key materials industries, Springer-Verlag, Berlin, Heidelberg, New York, 1980, pp. 105-117.

[6] Fischlin A., Conflicting objectives while maximising carbon sequestration by forests, in: Apps M.J., Price D.T. (Eds.), Forest ecosystems, forest management and the global carbon cycle, Springer-Verlag, Berlin, Heidelberg, 1996, pp. 163-172.

[7] Fleischer G., Schmidt W.-P., Functional unit for systems using natural raw materials, Int. J. LCA 1 (1996) 23-27.

[8] Frischknecht R., Knechtle N., Heating energy out of fuel oil, natural gas or wood? Bundesamt für Bundesamt für Umwelt, Wald und Landschaft (BUWAL), Bern, 2000 (in German).

[9] Hashimoto S., Nose M., Obara T., Moriguchi Y., Wood products: potential carbon sequestration and impact on net carbon emissions of industrialized countries, Environ. Sci. Policy 5 (2002) 183-193.

[10] Hofer P., Morf L., Taverna R., Richter K., $\mathrm{CO}_{2}$ sequestration in wood pools in the civilisatoric circle and emission effects of substitution of an increased use of wood, GEO Partner, Zürich, 2001 (in German).

[11] Hofer P., Taverna R., Richter K., Werner F., Buildings as wood pool, GEO Partner, Zürich, 2002 (in German).

[12] Hofer P., Taverna R., Richter K., Werner F., Sink capacity and material substitution of the Swiss buildings with regard to the national greenhouse gas inventory, GEO Partner, Zürich, 2002, (in German).

[13] IPCC, Climate change 1995; the science of climate change, Cambridge University Press, published for the International Panel on Climate Change (IPCC), Cambridge, 1996.

[14] IPCC, Evaluating approaches for estimating net emissions of carbon dioxide from forest harvesting and wood products; meeting report, Dakar, Senegal, 5-7 May 1998, in: Brown S., Lim B., Schlamadinger B. (Eds.), IPCC/OECD/IEA Programme on National Greenhouse Gas Inventories, Geneva, 1998.

[15] IPCC, Land use, land-use change, and forestry; a special report of the IPCC, Cambridge University Press, Cambridge, 2000.

[16] Jungmeier G., Werner F., Jarnehammer A., Hohenthal C., Richter K., Allocation in LCA of wood-based products, experiences of Cost Action E9, part I. Methodology, Int. J. LCA 7 (2002) 290-294.

[17] Karjalainen T., Model computations on sequestration of carbon in managed forests and wood products under changing climatic conditions in Finland, J. Environ. Manage. 47 (1996) 311-328.

[18] Künniger T., Richter K., Environmental comparison of electricity mains made from impregnated wood, reinforced concrete and corrosion-protected steel, Eidg. Materialprüfungs- und Forschungsanstalt (EMPA), Dübendorf, 1997 (in German).

[19] Künniger T., Richter K., Environmental assessment of railway sleepers in Switzerland; sleepers made of prestressed concrete, profiled steel and creosote-treated beech wood, Forschungs- und Arbeitsbericht 115/38, Eidg. Materialprüfungs- und Forschungsanstalt (EMPA), Dübendorf, 1998 (in German).

[20] Künniger T., Richter K., Environmental assessment of constructions of garden and landscape architecture, Eidg. Materialprüfungsund Forschungsanstalt (EMPA), Dübendorf, 2000 (in German).

[21] Künniger T., Richter K., Werner F., Life cycle inventory data of gravel, cement and concrete, Eidg. Materialprüfungs- und Forschungsanstalt (EMPA), Dübendorf, 2000 (in German). 
[22] Marland E., Marland G., The treatment of long-lived, carbon-containing products in inventories of carbon dioxide emissions to the atmosphere, Environ. Sci. Policy 6 (2003) 139-152.

[23] Marland G., Marland S., Should we store carbon in trees, Water Air Soil Pollut. Special issue on Natural sinks of $\mathrm{CO}_{2}, 64$ (1992) 181195.

[24] Marland G., Schlamadinger B., Forests for carbon sequestration or fossil fuel substitution? A sensitivity analysis, Biomass Bioenergy 13 (1998) 389-397.

[25] Matthews R.W., Nabuurs G.-J., Alexeyev V., Birdsey R.A., Fischlin A., Maclaren J.P., Marland G., Price D.T., WG3 summary: evaluation of the role of forest management and forest products in the carbon cycle, in: Apps M.J., Price D.T. (Eds.), Forest ecosystems, forest management and the global carbon cycle, Springer-Verlag, Berlin, Heidelberg, 1996, pp. 293-301.

[26] Niles J., Schwarze R., The value of careful carbon accounting in wood products, Clim. Change 49 (2001) 371-376.

[27] Quetting M., Wiegand J., Sell J., Indepth investigation on decision motives and on the image of wood for building construction in Switzerland, Eidg. Materialprüfungs- und Forschungsanstalt (EMPA), Dübendorf, 1999 (in German).

[28] Richter K., Gugerli H., Wood and wood products in comparative life cycle assessment, Holz Roh- Werks. 54 (1996) 225-231 (in German).

[29] SBSTA/UNFCCC, FCCC/SBSTA/2001/Misc.1: Issues related to emissions from forest harvesting and wood products; submission from Parties, in Subsidiary Body for Scientific and Technological Advice (Ed.), 2001.

[30] SBSTA/UNFCCC, FCCC/SBSTA/2003/Misc.1: Good practice guidance and other information on land use, land-use change and forestry; implications of harvested wood products accounting; submission from Parties, in Subsidiary Body for Scientific and Technological Advice (SBSTA) (Ed.), 2003.

[31] SBSTA/UNFCCC, FCCC/SBSTA/2003/Misc.1/Add.1: Good practice guidance and other information on land use, land-use change and forestry; implications of harvested wood products accounting; submission from Parties; addendum, in Subsidiary Body for Scientific and Technological Advice (SBSTA) (Ed.), 2003.
[32] SBSTA/UNFCCC, FCCC/SBSTA/2003/Misc.1/Add.2: Good practice guidance and other information on land use, land-use change and forestry; implications of harvested wood products accounting; submission from Parties; addendum, in Subsidiary Body for Scientific and Technological Advice (Ed.), 2003.

[33] Sedjo R.A., Forests to offset the greenhouse effect, J. For. 87 (1989) $12-15$.

[34] Skog K.E., Nicholson G.A., Carbon cycling through wood products: the role of wood and paper products in carbon sequestration, For. Prod. J. 48 (1998) 75-83.

[35] Thompson D.A., Matthews R.W., The storage of carbon in trees and timber, Forestry Commission Research information note 160, Edinburgh, 1989.

[36] UNFCCC/TP, FCCC/TP/2003/7: Estimation, reporting and accounting of harvested wood products, 2003.

[37] Werner F., Richter K., Life cycle assessment of parquet floorings, Holz-Zbl. 123 (1997) 1759 (in German).

[38] Werner F., Richter K., Bosshart S., Frischknecht R., Environmental comparison of interior works on the example of doorframes out of solid wood, particle board and steel, EMPA/ETH-Forschungsbericht, Dübendorf, Zürich, 1997 (in German).

[39] Werner F., Richter K., Life cycle assessment of facades, Innovative Fassaden; Tagung Baden-Baden, 7. und 8. November 2001, VDIBericht 1642, VDI-Gesellschaft Bautechnik, Düsseldorf, 2001, pp. 243-253 (in German).

[40] Werner F., Künniger T., Althaus H.-J., Richter K., Life cycle inventories of wood as fuel and construction material, Dübendorf, November 2002, Centre for life cycle inventories in the ETH domain, Dübendorf, 2003.

[41] Wiegand J., Quetting M., Results for building construction; investigation on the decision motives and knowledge on wood, SAH Bull. CSRB 3 (1999) 13-29 (in German).

[42] Wiegand J., Quetting M., Results in the remaining building sector and for furniture; investigation on the decision motives and knowledge on wood, SAH bulletin CSRB 3 (1999) 30-35 (in German).

[43] Winjum J.K., Brown S., Schlamadinger B., Forest harvests and wood products: sources and sinks of atmospheric carbon dioxide, For. Sci. 44 (1997) 271-284.

Annex. Product-specific GHG emissions (excluding renewable $\mathrm{CO}_{2}$-emissions), carbon pool capacity and weight of the wood products and their substitutes under study, taking into account national boundaries; import/export relations of final or semi-finished products are considered.

\begin{tabular}{|c|c|c|c|c|c|c|c|c|}
\hline & & $\begin{array}{c}\text { Fossil fuel } \\
\text { emissions } \mathrm{CH} \\
\mathrm{kg} \mathrm{CO}_{2} \text {-equiv. }\end{array}$ & $\begin{array}{c}\text { Fossil fuel } \\
\text { emissions abroad } \\
\mathrm{kg} \mathrm{CO}_{2} \text {-equiv. }\end{array}$ & $\begin{array}{l}\text { Total fossil fuel } \\
\text { emissions } \\
\mathrm{kg} \mathrm{CO}_{2} \text {-equiv. }\end{array}$ & $\begin{array}{c}\text { Wood as } \\
\mathrm{C} \text {-pool } \\
\mathrm{kg} \mathrm{CO}_{2} \text {-equiv. }\end{array}$ & $\begin{array}{l}\text { Weight product } \\
\qquad \begin{array}{c}\text { + repair }) \\
\mathrm{kg}\end{array}\end{array}$ & $\begin{array}{l}\text { Weight wood } \\
\qquad \begin{array}{c}\mathrm{u}=12 \%) \\
\mathrm{kg}\end{array}\end{array}$ & $\begin{array}{l}\text { Weight wood } \\
\qquad \begin{array}{c}\mathrm{u}=0 \%) \\
\mathrm{kg}\end{array}\end{array}$ \\
\hline \multirow[t]{3}{*}{ Laminated timber board $\left(\mathrm{m}^{2}\right)$} & Production & 16.27 & 13.72 & 30.00 & -121.03 & 95.9 & 74.0 & 66.1 \\
\hline & Disposal & 1.15 & 0.96 & 2.11 & 121.03 & & & \\
\hline & Total & 17.42 & 14.68 & 32.11 & & & & \\
\hline \multirow[t]{3}{*}{ 2-layered brick wall $\left(\mathrm{m}^{2}\right)$} & Production & 90.04 & 30.41 & & & & & \\
\hline & Disposal & 12.49 & 4.72 & & & & & \\
\hline & Total & 102.53 & 35.13 & & & & & \\
\hline \multirow[t]{3}{*}{ Glualam pillar (piece) } & Production & 2.66 & 27.45 & 30.11 & -44.16 & 34.6 & 27.0 & 24.1 \\
\hline & Disposal & 0.40 & 0.32 & 0.72 & 44.16 & & & \\
\hline & Total & 3.07 & 27.76 & 30.83 & & & & \\
\hline \multirow[t]{3}{*}{ Steel pillar (piece) } & Production & 0.70 & 84.76 & & & 37.1 & & \\
\hline & Disposal & & & & & & & \\
\hline & Total & 0.70 & 84.76 & & & & & \\
\hline
\end{tabular}


Annex. Continued.

\begin{tabular}{|c|c|c|c|c|c|c|c|c|}
\hline & & $\begin{array}{c}\text { Fossil fuel } \\
\text { emissions CH } \\
\mathrm{kg} \mathrm{CO}_{2} \text {-equiv. }\end{array}$ & $\begin{array}{c}\text { Fossil fuel } \\
\text { emissions abroad } \\
\mathrm{kg} \mathrm{CO}_{2} \text {-equiv. }\end{array}$ & $\begin{array}{l}\text { Total fossil fuel } \\
\text { emissions } \\
\mathrm{kg} \mathrm{CO}_{2} \text {-equiv. }\end{array}$ & $\begin{array}{c}\text { Wood as } \\
\mathrm{C} \text {-pool } \\
\mathrm{kg} \mathrm{CO}_{2} \text {-equiv. }\end{array}$ & $\begin{array}{l}\text { Weight product } \\
\qquad+ \text { repair }) \\
\text { kg }\end{array}$ & $\begin{array}{l}\text { Weight wood } \\
(\mathrm{u}=12 \%) \\
\mathrm{kg}\end{array}$ & $\begin{array}{l}\text { Weight wood } \\
\qquad \begin{array}{c}\mathrm{u}=0 \%) \\
\mathrm{kg}\end{array}\end{array}$ \\
\hline \multirow[t]{3}{*}{ Ceiling of wood beams $\left(\mathrm{m}^{2}\right)$} & Production & 23.58 & 26.22 & 49.80 & -92.24 & 188.3 & 56.4 & 50.4 \\
\hline & Disposal & 4.07 & 1.88 & 5.94 & 92.24 & & & \\
\hline & Total & 27.64 & 28.10 & 55.74 & & & & \\
\hline \multirow[t]{3}{*}{ Ceiling of reinforced concrete $\left(\mathrm{m}^{2}\right)$} & Production & 76.85 & 30.66 & & & 640.1 & & \\
\hline & Disposal & 67.30 & 18.83 & & & & & \\
\hline & Total & 144.15 & 49.49 & & & & & \\
\hline \multirow[t]{3}{*}{ Wood fibre insulation panel $\left(\mathrm{m}^{2}\right)$} & Production & 12.04 & 3.81 & 15.85 & -52.50 & 32.1 & 32.1 & 28.7 \\
\hline & Disposal & 0.47 & 0.37 & 0.85 & 52.50 & & & \\
\hline & Total & 12.51 & 4.18 & 16.69 & & & & \\
\hline \multirow[t]{3}{*}{ Mineral wool $\left(\mathrm{m}^{2}\right)$} & Production & 3.41 & 1.33 & & & 4.5 & & \\
\hline & Disposal & 0.21 & 0.07 & & & & & \\
\hline & Total & 3.61 & 1.40 & & & & & \\
\hline \multirow[t]{3}{*}{ Unlined joist construction $\left(\mathrm{m}^{2}\right)$} & Production & 33.24 & 9.55 & 42.78 & -68.69 & 99.1 & 42.0 & 37.5 \\
\hline & Disposal & 2.64 & 1.07 & 3.71 & 68.69 & & & \\
\hline & Total & 35.88 & 10.62 & 46.50 & & & & \\
\hline \multirow[t]{3}{*}{ Porous concrete pitched roof $\left(\mathrm{m}^{2}\right)$} & Production & 34.65 & 55.23 & 89.88 & -15.37 & 170.4 & 9.4 & 8.4 \\
\hline & Disposal & 3.90 & 1.54 & 5.44 & 15.37 & & & \\
\hline & Total & 38.55 & 56.77 & 95.32 & & & & \\
\hline \multirow[t]{3}{*}{ Wood palisade $\left(\mathrm{m}^{2}\right)$} & Production & 18.78 & 102.27 & 121.05 & -699.75 & 443.7 & 427.8 & 382.0 \\
\hline & Disposal & 4.27 & 0.44 & 4.72 & 699.75 & & & \\
\hline & Total & 23.05 & 102.71 & 125.77 & & & & \\
\hline \multirow[t]{3}{*}{ Wooden staircase, oak (m²) } & Production & 1.35 & 5.35 & 6.70 & -105.15 & 77.1 & 64.3 & 57.4 \\
\hline & Disposal & 0.84 & 0.66 & 1.50 & 105.15 & & & \\
\hline & Total & 2.19 & 6.01 & 8.20 & & & & \\
\hline \multirow[t]{3}{*}{ Ready-made concrete staircase (piece) } & Production & 29.24 & 50.11 & & & & & \\
\hline & Disposal & 21.50 & 6.07 & & & & & \\
\hline & Total & 50.74 & 56.18 & & & & & \\
\hline \multirow[t]{3}{*}{ 3-layered parquet flooring $\left(\mathrm{m}^{2}\right)$} & Production & 3.15 & 3.45 & 6.60 & -15.03 & 12.5 & 9.2 & 8.2 \\
\hline & Disposal & 0.22 & 0.15 & 0.37 & 15.03 & & & \\
\hline & Total & 3.38 & 3.59 & 6.97 & & & & \\
\hline \multirow[t]{3}{*}{ Ceramic tiles, enamelled $\left(\mathrm{m}^{2}\right)$} & Production & 0.82 & 21.72 & & & $18(+18)$ & & \\
\hline & Disposal & 0.97 & 0.37 & & & & & \\
\hline & Total & 1.79 & 22.09 & & & & & \\
\hline \multirow{3}{*}{$\begin{array}{l}\text { Wood panels, rough, + supporting } \\
\text { strips }\left(\mathrm{m}^{2}\right)\end{array}$} & Production & 0.44 & -0.33 & 0.11 & -18.81 & 11.6 & 11.5 & 10.3 \\
\hline & Disposal & 0.20 & 0.22 & 0.42 & 18.81 & & & \\
\hline & Total & 0.64 & -0.11 & 0.53 & & & & \\
\hline \multirow[t]{3}{*}{ Exterior plasterwork $\left(\mathrm{m}^{2}\right)$} & Production & 7.96 & 14.07 & & & $45(+45)$ & & \\
\hline & Disposal & 2.39 & 0.96 & & & & & \\
\hline & Total & 10.35 & 15.03 & & & & & \\
\hline \multirow[t]{3}{*}{ Doorframe, particleboard (piece) } & Production & 21.22 & 33.38 & 54.60 & -26.84 & $20(+20)$ & 16.4 & 14.7 \\
\hline & Disposal & 0.98 & 0.85 & 1.83 & 26.84 & & & \\
\hline & Total & 22.20 & 34.23 & 56.43 & & & & \\
\hline \multirow[t]{3}{*}{ Doorframe, steel (piece) } & Production & 19.66 & 74.02 & & & 90.0 & & \\
\hline & Disposal & 3.40 & 0.00 & & & & & \\
\hline & Total & 23.06 & 74.02 & & & & & \\
\hline \multirow[t]{3}{*}{ Wood furniture, particleboard (piece) } & Production & 16.25 & 24.93 & 41.18 & -26.84 & $20(+20)$ & 16.4 & 14.7 \\
\hline & Disposal & 0.98 & 0.85 & 1.83 & 26.84 & & & \\
\hline & Total & 17.23 & 25.78 & 43.01 & & & & \\
\hline \multirow[t]{3}{*}{ Steel furniture (piece) } & Production & 7.54 & 63.45 & & & 18.0 & & \\
\hline & Disposal & 0.00 & 0.00 & & & & & \\
\hline & Total & 7.54 & 63.45 & & & & & \\
\hline
\end{tabular}

